Jurnal Penelitian dan Pengabdian Kepada Masyarakat Bidang ilmu Pendidikan

\title{
Upaya Meningkatkan Prestasi Belajar Siswa SMA melalui Model Pembelajaran Picture And Picture
}

\author{
M. Amin \\ Program Studi Pendidikan Bahasa dan Sastra Indonesia, STKIP Yapis Dompu \\ E-mail: m.aminyapis@gmail.com
}

Article History: Received: 2022-02-11 || Revised: 2022-02-15 || Published: 2022-02-28

Sejarah Artikel : Diterima: 2022-02-11 || Direvisi: 2022-02-15 || Dipublikasi: 2022-02-28

\begin{abstract}
This research is a classroom action research that aims to improve student learning outcomes, this is motivated by the incompleteness of student learning outcomes due to inappropriate learning strategies used. Based on the theory of learning history, to solve this problem, the researchers tried to apply the Picture and Picture Model based on Microsoft Power Point in the learning process. The purpose of this research is to improve the learning achievement of students who study with a picture and picture model based on Microsoft PowerPoint in the subject of History, From the results of research data processing, the percentage of learning completeness in Cycle I was 83.87\%, in Cycle II it was $87.10 \%$. From there, it was seen that the increase from each cycle I to Cycle II was $3.23 \%$. These results indicate an increase in cycle I to cycle II. So it can be concluded that the application of the picture and picture model based on Microsoft Power Point can improve student achievement in class X5 SMA Negeri I Magelewa in the 2021/2022 academic year.
\end{abstract}

Keywords: Effort, Improvement, Student Achievement, Picture and Picture.

\begin{abstract}
Abstrak
Penelitian ini adalah penelitian tindakan kelas yang bertujuan untuk meningkatkan hasil belajar siswa, hal ini dilatarbelakangi oleh belum tuntasnya hasil belajar siswa ini di sebabkan karna tidak sesuainya strategi pembelajaran yang di gunakan. Berdasarkan teori belajar sejarah, untuk memecahkan masalah tersebut maka peneliti mencoba menerapkan dengan menggunakan Model Picture and Picture Berbasis Microsoft Power Point dalam proses pembelajaran. Adapun tujuan penelitian ini yaitu Untuk meningkatkan prestasi belajar siswa yang belajar dengan model picture and picture berbasis Microsoft PowerPoin pada mata pembelajaran Sejarah, dari hasil pengolahan data penelitian, diperoleh persentase ketuntasan belajar pada Siklus I sebesar $83,87 \%$, pada Siklus II sebesar $87,10 \%$ dari situ dilihat peningkatan dari masing-masing siklus I sampai siklus II sebesar 3,23\%. Hasil ini menunjukkan adanya peningkatan pada siklus I kesiklus II. Sehingga dapat disimpulkan bahwa dengan penerapan model picture and picture berbasis Microsoft Power Point dapat meningkatkan prestasi belajar siswa kelas X X $_{5}$ SMA Negeri I Manggelewa Tahun Pembelajaran 2021/2022.
\end{abstract}

Kata kunci: Upaya, Meningkatkan, Prestasi siswa, Picture and Picture.

\section{PENDAHUluan}

Pembangunan nasional membutuhkan Sumber Daya Manusia (SDM) yang berkualitas yang memiliki sikap dan tekad kemandirian. Kualitas SDM dapat ditingkatkan dengan pendidikan. Parameter penilaian kualitas SDM ini adalah semangat dan kemampuan mengoperasikan dan mengaplikasikan teknologi. Program Pembinaan Pendidikan Menengah yang mencakup Sekolah Menengah Atas (SMA), Sekolah Menengah Kejuruan (SMK) dan Madrasah Aliyah (MA) ditujukan antara lain untuk meningkatkan kualitas pendidikan menengah sebagai landasan bagi siswa untuk melanjutkan pendidikan ke jenjang pendidikan yang lebih tinggi dan kebutuhan dunia kerja, Kegiatan pokok dalam upaya peningkatan kualitas dan relevansi pendidikan menengah dengan menyusun kurikulum yang berbasis kompetensi sesuai dengan kebutuhan dan potensi pembangunan daerah, mampu meningkatkan kreativitas guru sesuai dengan kapasitas siswa serta menekankan perlunya keimanan, dan ketaqwaan, wawasan kebangsaan, kesehatan jasmani, kepribadian yang berakhlak mulia, beretos kerja, memahami hak dan kewajiban, serta meningkatkan penguasaan ilmu-ilmu dasar (sejarah, sains dan teknologi, bahasa dan sastra, ilmu sosial). 
Sejarah merupakan salah satu pembelajaran yang sangat penting diajarkan di sekolah. Oleh sebab itu pemerintah terus berusaha meningkatkan mutu pembelajaran Sejarah, diantaranya melengkapi sarana dan prasarana, penyempurnaan kurikulum, meningkatkan kualitas guru melalui penataran-penataran maupun pendidikan formal. Namun kenyataannya di lapangan menunjukan bahwa usaha-usaha tersebut masih belum memberikan hasil yang optimal, meskipun telah diupayakan dengan berbagai cara untuk meningkatkan perstasi belajar siswa, namun pendidikan di sekolah saat ini masih dihadapkan pada permasalahan siswa yang berprestasi rendah, khususnya pada pembelajaran Sejarah. Hal ini menuntut pentingnya guru memilih metode, strategi dan pendekatan-pendekatan pembelajaran yang sesuai guna meningkatkan hasil belajar siswa pada pembelajaran Sejarah,

Beberapa model pembelajaran yang belum diterapkan dalam proses pembelajaran Sejarah di SMA Negeri 1 Manggelewa adalah Model pembelajaran Picture and picture melalui powerpoint dan masih banyak model-model lainnya. Dalam proses belajar sejarah model pembelajaran dengan menggunakan Picture and picture melalui powerpoint bertujuan untuk memberikan bantuan kepada siswa atau peserta didik agar dapat mencapai hasil belajar sejarah secara optimal, namun pada kenyataannya masih banyak siswa yang mengalami kesulitan dalam memahami materi sejarah walaupun pendekatan bimbingan belajar telah diterapkan, sehingga menyebabkan hasil belajar sejarah tetap rendah.

Berdasarkan observasi awal yang dilakukan oleh peneliti, SMA Negeri 1 Manggelewa memiliki problematika yaitu hasil belajar siswa. Rendahnya hasil belajar siswa terlihat dari hasil ulangan siswa yang masih belum mencapai KKM yang ditentukan sekolah yakni 65, hal ini terlihat dari hasil ulangan harian semester ganjil Tahun Pembelajaran 2021/2022, seperti terlihat pada tabel 1 dibawah ini.

Tabel 1. Rata-rata nilai hasil ulangan harian siswa pada mata pembelajaran sejarah kelas X SMA Negeri 1 Manggelewa Tahun Pembelajaran 2021/2022.

\begin{tabular}{c|c|c|c}
\hline No & Kelas & Jumlah Siswa & Rata- rata Nilai ulangan harian \\
\hline 1 & $\mathrm{X} 1$ & 31 & 67 \\
\hline 2 & $\mathrm{X} 2$ & 24 & 67 \\
\hline 3 & $\mathrm{X} 3$ & 26 & 66 \\
\hline 4 & $\mathrm{X} 4$ & 26 & 68 \\
\hline 5 & $\mathrm{X} 5$ & 31 & 65 \\
\hline 6 & $\mathrm{X} 6$ & 25 & 68 \\
\hline 7 & $\mathrm{X} 7$ & 26 & 65 \\
\hline
\end{tabular}

(Sumber : Arsip data nilai guru sejarah SMAN 1 Manggelewa)

Berdasarkan hasil ulangan harian siswa nilainya rata-rata hanya mencapai 67. Pembelajaran sejarah di SMA Negeri 1 Manggelewa Model picture and picture berbasis Microsoft Power Point sebagai model pembelajaran dapat digunakan untuk menyampaikan materi pembelajaran berupa gambar yang dapat menegaskan poin-poin dari materi pembelajaran. Siswa diberikan gambargambar untuk diurutkan menjadi urutan yang logis dalam bentuk narasi yang dipresentasikan di depan kelas, Berdasarkan tabel 1 diatas, terlihat bahwa rata-rata nilai hasil ulangan hariansejarah siswa kelas $\mathrm{X}_{5}$ SMA Negeri 1 Manggelewa masih berada dibawah Kriteria Ketuntasan Minimal (KKM) yang telah ditetapkan yaitu 65. Jika masalah yang dikemukakan diatas tidak diatasi maka tujuan peningkatan mutu pendidikan dan pembelajaran sejarah sulit dicapai. Untuk mengatasi masalah diatas diharapkan guru dapat menerapkan berbagai model pembelajaran yang berorientasi pada pembelajaran siswa aktif yang diantaranya adalah dengan menggunakan picture and picture melalui powerpoint.

Berdasarkan latar belakang masalah diatas, maka mendorong penulis untuk mengadakan penelitian lebih lanjut yang berjudul "Peningkatan prestasi belajar melalui model Picture and Picture Semester ganjil di SMA Negeri 1 Manggelewa Tahun Pembelajaran 2021/2022".

\section{METODE PENELITIAN}

Penelitian yang digunakan adalah Penelitian Tindakan Kelas (Classroom Action Research) dengan menggunakan siklus tapi jika kedua siklus belum berhasil akan dilanjutkan kesiklus yang selanjutnya yaitu siklus ketiga dan seterusnya, disetiap siklus terdiri atas 4 tahap, yaitu perencanaan, tindakan, observasi, dan refleksi, yang menjadi subyek dalam penelitian ini adalah 
siswa yaitu siswa kelas $X_{5}$ pada SMA Negeri 1 Manggelewa tahun Pembelajaran 2021/2022 yaitu Siswa kelas $\mathrm{X}_{5}$ yang mempunyai jumlah siswa 31 anak yang terdiri dari 16 laki-laki dan 15 perempuan, sedangkan Teknik pengumpulan data yang digunakan sebagai berikut: 1) Metode tes yaitu untuk mengukur prestasi belajar menggunakan Model Picture and Picture, 2) Observasi yaitu untuk mengetahui aktivitas siswa dan aktifitas guru dalam penerapan model Model Picture and picture, 3) Dokumentasi yaitu untuk mendapatkan data tentang nama-nama siswa, RPP, Silabus, materi dan lain-lain, 4) Wawancara yaitu mewawancarai siswa dan guru untuk mengetahui sebagai mana kemampuan siswa untuk mencapai prestasi yang dicapai, Data yang terkumpul selanjutnya dianalisis dengan menggunakan analisis kuantitatif digunakan statistic deskriptif untuk melihat skor rata-rata persentase dan ketuntasan prestasi belajar siswa

\section{HASIL DAN PEMBAHASAN}

\section{A. Hasil Penelitian}

Penelitian tindakan kelas ini dilakukan untuk meningkatkan hasil belajar siswa kelas $\mathrm{X}_{5}$ SMA Negeri 1 Manggelewa Tahun Pembelajaran 2021/2022 pada materi pokok masyarakat indonesia masa pra-aksara dan masa aksara menggunakan Model picture and picture, pelaksanaan penelitian ini mulai dari tanggal 01 Oktober sampai dengan 15 Nopember 2013. Hasil penelitian ini berupa data kualitatif dan kuantitatif, yaitu data kualitatif didapat dari observasi aktifitas siswa dan guru pada setiap pertemuan. Sedangkan secara kuantitatif didapat dari hasil evaluasi siswa yang akan memberikan jawaban dari hasil belajar siswa. Data yang terkumpul dalam penelitian ini berasal dari hasil evaluasi yang akan dipaparkan dalam masing-masing Siklus.

\section{a. Perencanaan}

Pada tahap ini dilakukan beberapa persiapan sebelum penelitian tindakan kelas dilaksanakan. Persiapan ini meliputi:

1) Pembuatan perangkat belajar berupa Rencana Pelaksanaan Pembelajaran (RPP Lampiran II, hal: 82).

2) Koordinasi dengan guru bidang studi yang bertindak sebagai pengamat (Observer) dalam proses belajar mengajar.

3) Melakukan evaluasi berupa tes tertulis untuk mengetahui kemampuan siswa dalam pokok bahasan masyarakat Indonesia masa pra-aksara dan masa aksara.

\section{b. Pelaksanaan Tindakan}

Pelaksanaan tindakan pada Siklus I yaitu dilaksanakan dalam tiga kali pertemuan, pertama dilaksanakan pada tanggal 08 Oktober, 09 oktober 2013 untuk materi pembelajaran Picture And Picture Berbasis Microsof Powerpint di SMA Negeri 1 Manggelewa, dan pada akhir pembelajaran dilakukan tes evaluasi. Pelaksanaan tindakan pembelajaran dilakukan dengan Rencana Pelaksanaan Pembelajaran (RPP), namun pemahaman siswa tentang materi yang diajarkan belum maksimal atau belum sesuai dengan harapan yang ingin dicapai dalam penelitian tersebut. Sehingga belum mencerminkan kegiatan pembelajaran yang aktif. Namun sebelum lanjut ke Siklus berikutnya, peneliti melakukan bimbingan terhadap siswa yang mendapatkan nilai kurang dari 65 secara khusus.

\section{c. Hasil Observasi}

Berdasarkan hasil observasi yang dilaksanakan oleh guru bidang studi siklus I maka data aktifitas siswa dapat dilihat pada tabel dibawah ini:

Tabel 2. Data hasil Observasi Aktivitas belajar siswa dengan menggunakan Picture and Picture Antar Pertemuan

\begin{tabular}{clcc}
\hline No & \multicolumn{1}{c}{ Aspek yang di observasi } & $\begin{array}{c}\text { Rerata indikator } \\
\text { Pertemuan 1 }\end{array}$ & $\begin{array}{c}\text { Rerata indikator } \\
\text { Pertemuan 2 }\end{array}$ \\
\hline 1 & Antusiasi siswa dalam mengikuti kegiatan pembelajaran & 1,75 & 3,25 \\
\hline 2 & Interaksi siswa dengan guru & 2,25 & 2,25 \\
\hline 3 & Interaksi siswa dengan siswa & 2,25 & 3,00 \\
\hline 4 & Aktifitas siswa dalam mengerjakan soal latihan & 2,00 & 3,25 \\
\hline 5 & Aktivitas siswa dalam mengerjakan evaluasi & 2,00 & 2,25 \\
\hline 6 & Aktivitas siswa dalam mengikuti pembelajaran & 2,25 & 2,25 \\
\hline 7 & Partisipasi siswa dalam menyimpulkan hasil belajar & 1,75 & 3,25 \\
\hline
\end{tabular}




$\begin{array}{rcc}\text { Jumlah } & 14,25 & 18,5 \\ \text { Rerata } & 2,03 & 2,64 \\ \text { Kategori } & \text { Kurang Aktif } & \text { Cukup Akt }\end{array}$

Tabel 3. Data hasil Observasi Aktivitas guru dengan menggunakan Picture And Picture siklus I (Pertemuan I dan II)

\begin{tabular}{ccc}
\hline Pertemuan & Skor & Kategori \\
\hline I & 2,1 & Kurang aktif \\
\hline II & 3,1 & Aktif \\
\hline
\end{tabular}

\section{d. Hasil Evaluasi}

Hasil evaluasi pada Siklus I menunjukkan bahwa persentase siswa yang mendapat nilai maksimal 65 adalah 83,87 \% kurang dari 85 \% yang terdiri dari 26 orang siswa. Ini berarti bahwa indikator penelitian belum mencapai ketuntasan belajar. Hasil evalusi ini juga menunjukkan bahwa terdapat 5 (lima) siswa yang hanya mampu menyerap materi $40 \%$ dan $60 \%$. Sehingga sebelum lanjut ke siklus berikutnya dilakukan upaya perbaikan terlebih dahulu dengan melakukan bimbingan secara individual atau secara khusus kepada siswa yang mendapatkan nilai kurang dari 65. Hal ini dapat dilihat pada table 4 dibawah ini.

Table 4. Data Hasil Evaluasi kelas X5 pada siklus 1 dengan menggunakan picture and picture.

\begin{tabular}{|c|c|c|c|c|c|c|c|}
\hline \multirow[b]{2}{*}{ No } & \multirow[b]{2}{*}{ Nama siswa } & \multicolumn{5}{|c|}{ Skor soal } & \multirow[b]{2}{*}{ Skor } \\
\hline & & 20 & 20 & 20 & 20 & 20 & \\
\hline 1 & Wiwin winarti & 20 & 10 & 10 & 20 & 15 & 75 \\
\hline 2 & Arifin & 15 & 15 & 10 & 20 & 10 & 70 \\
\hline 3 & Amar & 15 & 5 & 20 & 20 & 15 & 75 \\
\hline 4 & Misnah & 20 & 10 & 10 & 20 & 20 & 80 \\
\hline 5 & Yusuf & 20 & 15 & 20 & 10 & 20 & 85 \\
\hline 6 & Nukrah & 15 & 5 & 10 & 15 & 10 & 55 \\
\hline 7 & Sukardin & 20 & 10 & 10 & 15 & 15 & 70 \\
\hline 8 & Dewi Anggriani & 15 & 15 & 15 & 20 & 15 & 80 \\
\hline 9 & Kaharuddin & 10 & 20 & 10 & 10 & 10 & 60 \\
\hline 10 & Sumarni & 10 & 15 & 20 & 20 & 15 & 80 \\
\hline 11 & Syahrul & 20 & 20 & 20 & 20 & 20 & 100 \\
\hline 12 & Abdillah & 15 & 10 & 15 & 20 & 10 & 70 \\
\hline 13 & Husni Mubarrak & 20 & 10 & 10 & 10 & 10 & 60 \\
\hline 14 & M. akbar & 20 & 15 & 15 & 15 & 5 & 65 \\
\hline 15 & Junaiddin & 5 & 5 & 5 & 10 & 15 & 40 \\
\hline 16 & Mus Mulyadin & 20 & 20 & 20 & 20 & 20 & 100 \\
\hline 17 & Jainuddin & 20 & 15 & 15 & 10 & 5 & 65 \\
\hline 18 & Irawati & 20 & 15 & 15 & 15 & 10 & 75 \\
\hline 19 & Didin Supriadin & 15 & 20 & 20 & 10 & 15 & 80 \\
\hline 20 & Syairullah & 20 & 10 & 15 & 15 & 10 & 70 \\
\hline 21 & Nuraini & 20 & 20 & 20 & 20 & 5 & 85 \\
\hline 22 & Ardianti & 20 & 10 & 15 & 10 & 15 & 70 \\
\hline 23 & Rohana & 10 & 10 & 15 & 15 & 5 & 55 \\
\hline 24 & Desi Arisanti & 20 & 20 & 20 & 20 & 10 & 90 \\
\hline 25 & Nurmala & 20 & 20 & 15 & 10 & 15 & 80 \\
\hline 26 & Edi Hidayat & 20 & 20 & 20 & 10 & 15 & 85 \\
\hline 27 & Ningsih & 20 & 20 & 15 & 10 & 15 & 80 \\
\hline 28 & Sri Jumiati & 20 & 15 & 10 & 15 & 5 & 65 \\
\hline 29 & Yuliastuti & 20 & 20 & 20 & 10 & 10 & 80 \\
\hline 30 & Julkarnain & 20 & 20 & 15 & 20 & 10 & 85 \\
\hline \multirow[t]{2}{*}{31} & Misratul Adwiah & 20 & 20 & 20 & 10 & 10 & 80 \\
\hline & & \multicolumn{5}{|c|}{ Jumlah } & 2330 \\
\hline \multicolumn{2}{|c|}{ Nilai maksimum } & \multicolumn{6}{|c|}{100} \\
\hline \multicolumn{2}{|c|}{ Nilai minimum } & \multicolumn{6}{|c|}{40} \\
\hline \multicolumn{2}{|c|}{ Jumlah siswa yang tuntas } & \multicolumn{6}{|c|}{26} \\
\hline \multicolumn{2}{|c|}{ Jumlah siswa tidak tuntas } & \multicolumn{6}{|c|}{5} \\
\hline \multicolumn{2}{|c|}{ Presentase ketuntasan klasikal } & \multicolumn{6}{|c|}{$\mathbf{K K}=\frac{26}{31} \times 100 \%$} \\
\hline \multicolumn{2}{|c|}{ Presentase ketuntasan klasikal } & \multicolumn{6}{|c|}{$83,87 \%$} \\
\hline
\end{tabular}




\section{e. Hasil Refleksi}

Berdasarkan hasil penelitian siklus I baik hasil evaluasi dalam penguasan materi maupun hasil observasi proses belajar mengajar yang ditetapakan tidak tercapai. Dalam hal ini refleksi yang dimaksud adalah untuk mengetahui kekurangan-kekurangan yang terjadi selama proses pembelajara antara lain:

1) Masih banyak siswa yang kurang mampu dalam mengerjakan soal dengan benar pada saat proses pembelajaran

2) Masih banyak siswa yang ribut dan kurang paham dalam pembelajaran

3) banyaknya waktu yang tersita pada saat latihan.

Untuk itu dilakukan perbaikan terhadap tindakan siklus II, antara lain:

a) Guru membantu siswa yaitu dengan memberikan Pemahaman dan melatih siswa untuk dapat mengerjakan soal dengan benar.

b) Guru berusaha agar mengontrol siswa pada saat pembelajaran supaya siswa tidak ribut dan aktif dalam melaksanakan kegiatan pembelajaran.

Pada saat menutup kegiatan pembelajaran tidak bisa dilaksanakan seefisien mungkin. Hal ini disebabkan karena banyaknya waktu yang tersita pada saat latihan. Untuk itu, peneliti harus menggunakan waktu seefisien mungkin pada Siklus berikutnya.

\section{B. Pembahasan}

Berdasarkan hasil analisis tindakan dan hasil evaluas pada siklus I menunjukan bahwa nilai rata-rata kelas sebesar 75,16 dengan presentase ketuntasan belajar 83,87\%.Ini berarti ketuntasan belajar siswa belum tercapai seperti yang diharapkan. Sehingga sebelum melanjutkan pembelajaran ke siklus berikutnya dilakukan upaya perbaikan dan penyempurnaan terlebih dahulu, pada Siklus I (dengan menggunakan picture) hasil evaluasi menunjukkan nilai rata-rata siswa sebesar 75,16 dengan persentase ketuntasan 83,87 \%. Hasil evaluasi Siklus I berada di bawah indikator keberhasilan yang ditetapkan. Menurut Nurkancana, (1986) ada tiga faktor yang mempengaruhi hasil belajar, yaitu faktor internal, faktor eksternal, dan faktor pendekatan belajar. Belum tuntasnya hasil belajar disebabkan karena faktor pendekatan belajar, yaitu siswa belum melaksanakan strategi belajar dengan maksimal.

Pada Siklus II (dengan menggunakan picture and picture) merupakan perbaikan dari Siklus I. Untuk mendapatkan hasil yang lebih baik, lebih ditekankan strategi dalam membimbing siswa pada saat mengerjakan soal-soal latihan. Nilai rata-rata siswa sebesar 76,29 dan hasil evaluasi menunjukkan persentase ketuntasan sebesar 87,10 \%. Jadi, target yang diterapkan telah tercapai, dalam penelitian ini, dengan menerapkan Penerapaan Strategi Belajar dengan menggunakan metode picture and picture, maka siswa lebih aktif dalam mengerjakan soal yang diberikan guru dan hasil evaluasi belajar siswa mengalami peningkatan, karena dengan Penerapaan strategi Belajar dengan menggunakan metode picture and picture dapat mengembangkan kemampuan motorik yang sebelumnya dilakukan diagnosis agar kegiatan itu bermanfaat bagi pengembangan motorik siswa. Sagala (2005: 217) mengemukakan bahwa metode latihan merupakan suatu cara mengajar yang baik untuk menanamkan kebiasaankebiasaan tertentu. Juga sebagai sarana untuk meperoleh suatu ketangkasan dan keterampilan.

Dari uraian di atas menunjukkan bahwa melalui penerapan Strategi Belajar dengan menggunakan metode picture and picture dapat meningkatkan aktivitas Belajar siswa kelas $\mathrm{X}_{5}$ SMA Negeri 1 Manggelewa pada pokok bahasan masyarakat indonesia masa pra-aksara dan masa aksara Tahun Pembelajaran 2021/2022.

Tabel 5. Analisis hasil belajar Siswa

\begin{tabular}{clccc}
\hline No & Uraian & Siklus I & Siklus II \\
\hline 1. & Nilai tertinggi & 100 & 100 \\
\hline 2. & Nilai terendah & 40 & 50 \\
\hline 3. & Nilai rata-rata & 75,16 & 76,29 \\
\hline 4. & Jumlah peserta tes & 31 & 31 \\
\hline 5. & Jumlah siswa yang tuntas & 26 & 27 \\
\hline 6. & Jumlah siswa yang tidak tuntas & 5 & 4 \\
\hline
\end{tabular}




\begin{tabular}{clcc}
\hline 7. & Persentase siswa yang tuntas & $83,87 \%$ & $87,10 \%$ \\
\hline 8. & Persentase siswa tidak tuntas & $16,13 \%$ & $12,90 \%$ \\
\hline
\end{tabular}

Berdasarkan tabel diatas, diketahui bahwa terdapat peningkatan hasil belajar siswa, ini terlihat dengan jelas pada Tabel 5 bahwa nilai rata-rata pada Siklus I dan II mengalami peningkatan yaitu Siklus I sebanyak 75,16 dan Siklus II sebanyak 76,29. Kemudian nilai terendah siswa juga mengalami peningkatan pada tiap-tiap siklus. Siklus I nilai terendahnya 40 Dan Siklus II adalah 50, Prestasi belajar dipengaruhi oleh cara seorang dalam belajar. Setiap orang memiliki kebiasaan ataupun cara belajar yang berbeda-beda. Ada seseorang yang memiliki cara belajar yang tergolong baik dan ada pula seseorang yang memiliki cara belajar yang tergolong kurang baik. Berikut akan dikutip pendapat para ahli yang berkaitan dengan cara-cara belajar dikatakan baik.

Dalam buku Berbagai Teknik Meningkatkan Kreativitas Belajar Anak dijelaskan bahwa: "Cara yang belajar yang baik dapat dilihat dari: (a) Kemampuannya dalam membuat rencana belajar, (b) Kemampuanya dalam membaca buku, (c) Kemampuannya dalam menghafal berbagai materi pelajaran dan (d) Kemampuannya mempersiapkan diri dalam menghadapi ujian" (Semiawan, 2000 : 112). Sementara itu menurut The Liang Gie menjelaskan bahwa: "Seseorang yang dapat dikatakan memiliki cara belajar yang baik, bila ditandai oleh adanya: (a) Kemampuan dalam membaca, (b) Kemampuan dalam membuat ringkasan pelajaran, (c) Kemampuan menghafal pelajaran" (The Liang Gie, 1998 : 39), dengan demikian dari kedua pendapat ahli tersebut di atas, dapat disimpulkan bahwa ciri-ciri orang memiliki cara dalam belajar adalah: (a) Mampu membuat rencana belajar, (b) Mampu membaca buku secara lebih baik, (c) Mampu membuat ringkasan-ringkasan yang tepat, (d) Mampu menghafal materimateri pelajaran serta (e) Selalu menyiapkan diri dalam menghadapi ujian. Berikut ini akan dijelaskan secara singkat masing-masing ciri-ciri orang yang memiliki cara belajar yang baik tersebut.

Cara-cara belajar yang dimiliki oleh seseorang dimaksudkan dalam rangka untuk mendapatkan suatu keterampilan, pengetahuan, kecakapan atau sikap-sikap yang dalam hal ini cara belajarnya. Cara belajar tidaklah secara atau terjadi seketika itu, tetapi hal tersebut diperoleh melalui proses latihan yang berulang-ulang dan disertai dengan kesadaran dan akhirnya terjadi secara otomatis bila berhadapan dengan hal yang serupa, pada mulanya seseorang yang memiliki kebiasaan atau cara-cara belajar yang biasa dilakukan yaitu dengan cara yang dirasakan atau dianggap paling mudah untuk dilaksanakan artinya bahwa cara-cara tersebut tanpa mengalami gangguan. Cara-cara itulah yang dilakukan berulang-ulang tetap, seragam, sehingga akhirnya setiap perbuatan belajar yang dilakukan diikuti dengan cara-cara tersebut yang lamban laun tanpa diikuti kesadaran.

Dalam hal ini suatu pendapat mengemukakan sebagai berikut: "Terjadinya cara-cara belajar itu melalui kecenderungan seseorang untuk mengikuti upaya yang kurang hambatannya. Dengan cara ini seseorang cenderung untuk mengikuti dengan jalan jumlah rintangan yang paling kecil. Terjadinya dengan kesengajaan dan hati-hati untuk membentuk pola reaksi secara otomatis" (Moh. Arifin, 1996 : 90).

Selanjutnya ahli lain mengungkapkan sebagai berikut cara belajar pada umumnya diperoleh melalui latihan, asal mulanya terjadi adalah melalui dua cara yang umum yakni (a) Melalui kecenderungan orang untuk mengikuti upaya yang kurang hambatannya. Maksudnya pada mulanya seseorang melakukan sesuatu manakala hal itu dilaksanakannya menurut suatu cara tertentu karena cara itu adalah yang termudah dan tidak mengalami suatu gangguan. Kemudian cara itu dilaksanakannya menurut secara berulang-ulang, (b) Melalui tindakan sengaja dan hati-hati membentuk suatu pola reaksi secara otomatis (Syam Isbani, 1992 : 20), menurut kedua pendapat tersebut di atas, memiliki pola pemikiran yang sama, artinya tidak terjadi perbedaan dalam memberikan penjelasan, yang mana dari kedua pendapat tersebut menunjukkan bahwa terbentunya cara dalam belajar pada diri seseorang melalui dua cara yaitu: a) Melalui kecenderungannya mengikuti upaya yang kurang hambatannya, dan b) Secara sengaja membentuk suatu pola interaksi yang baru, kemudian cara tersebut dilakukan berulang-ulang hingga menjadi otomatis. 


\section{SIMPULAN DAN SARAN}

\section{A. Simpulan}

Berdasarkan hasil penelitian dan pembahasan dapat dikemukakan bahwa:

1. Peningkatan Prestasi belajar siswa yang belajar dengan menggunakan picture and picture pada mata pembelajaran Sejarah Pada Siklus I dari pertemuan I dan II menunjukkan nilai rata-rata siswa sebesar 75,16 dengan persentase ketuntasan 83,87 \%. Hasil evaluasi Siklus I berada di bawah indikator keberhasilan yang ditetapkan.

2. Peningkatan Prestasi belajar siswa yang belajar dengan model picture and picture pada mata pembelajaran Sejarah, nilai rata pada siklus II dari pertemuan I dan II menunjukan nilai rataratanya siswa sebesar 76,29 dan hasil evaluasi menunjukkan persentase ketuntasan sebesar $87,10 \%$. Jadi, target yang diterapkan telah tercapai.

3. Jadi peningkatan prestasi belajar siswa pada mata pembelajaran Sejarah yang belajar dengan menggunakan model picture and picture dengan bantuan Microsoft PowerPoin, Prestasi Belajar dengan menggunakan metode picture and picture dapat meningkatkan Pemahamaan dan prestasi Belajar siswa kelas $\mathrm{X}_{5}$ SMA Negeri 1 Manggelewa. Ketuntasan ini dilihat dari persentase ketuntasan yang diperoleh siswa pada Siklus I dengan menggunakan model picture and picturesebesar 83,87 \%, dan pada Siklus II dengan menggunakan model picture and picturese besar $87,10 \%$. dan besar peningkatan dari tiap-tiap siklus dari siklus I sampai siklus ke II sebesar 3,23\%. hasil ini menunjukan adanya peningkatan dan tercapainya ketuntasan belajar yang diharapkan.

\section{B. Saran}

Berdasarkan kesimpulan di atas, maka peneliti dapat memberikan saran-saran sebagai berikut:

1. Bagi siswa yang ingin meningkatkan hasil belajarnya agar berpatisipasi aktif dalam menyelesaikan soal-soal tes ddengan menggunakan model picture and picture dengan bantuan microsoft power point.

2. Bagi guru - guru di SMA N 1Manggelewa dapat menggunakan model picture and picture dengan bantuan microsoft power point dalam proses pembelajaran.

3. Bagi peneliti lain dapat memanfaatkan waktu lebih banyak lagi agar tidak berpengaruh terhadap hasil belajar siswa.

4. Bagi lembaga STKIP Yapis Dompu diharapkan agar dapat menyiapkan fasilitas yang cukup memadai sehingga dapat digunakan sebagai sarana pendukung, seperti perpustakaan.

\section{DAFTAR RUJUKAN}

Abu Ahmadi. 2005. Strategi Belajar Mengajar. Bandung : Pustaka Setia.

Ad Rooijakkers. 1986. Mengajar dengan Sukses. Jakarta : PT. Gramedia.

Arifin, A., Ma'ruf, F., \& Yasin, I. (2020). Efektivitas Belajar Al-Qur'an Dengan menggunakan Aplikasi Hijaiyah Berbasis Budaya Lokal "Nggahi Mbojo" (Bahasa Bima) Pada Lansia di Kabupaten Dompu. Ainara Journal (Jurnal Penelitian Dan PKM Bidang Ilmu Pendidikan), 1(1), 24-30. https://doi.org/10.54371/ainj.v1i1.10

Bloom, Benyamin S., 1976. Handbook on Formative and Summative Evaluation of Student Learning. New York :McGraw- Hill Book Company.

Depdiknas. 2008. Pengembangan dan Penerapan Model Pembelajaran Berbasis Kompetensi. Jakarta : Depdiknas.

Eko. Model Pembelajaran Picture and Picture. [Online]. Tersedia :Http://raseko.blogspot.com/2013/05/model-pembelajaran-picture-and-picture.html [20 Juli 2013]

Gagne, Robert M. 1978. The Conditions of Learning. New York : Holt, Rinehart and Winston, Inc.

KTSP, dkk. Kurikulum Tingkat Satuan Pendidikan. Jakarta : Badan Standar Nasional . 
Ma'ruf, F. (2021). Pengembangan Game Edukasi Berbasis Flash Sebagai Sarana Belajar Siswa PAUD. Ainara Journal Uurnal Penelitian Dan PKM Bidang Ilmu Pendidikan), 2(3), 143-147. https://doi.org/10.54371/ainj.v2i3.68

Nana Sudjana. 1995. Penilaian Hasil Proses Belajar Mengajar. Bandung: PT. Remaja Rosda Karya

Nana Sudjana. 1996. Metode Statistik. Bandung : Tarsito.

Nurul Zuriah. 2006. Metodologi Penelitian Sosial dan Pendidikan. Jakarta : PT. Bumi Aksara.

S. Nasution. 2008. Berbagai Pendekatan dalam Proses Belajar dan Mengajar. Jakarta : PT. Bumi Aksara.

Suharsimi Arikunto,. 1999. Dasar-Dasar Evaluasi Pendidikan . Jakarta : Bumi Aksara.

Syahrani. 2011. "Penerapan Model Pembelajaran Picture and Picture untuk meningkatkan hasil belajar sains siswa kelas IV SDN 008 Bumi Ayu Kecamatan Dumai Timur tahun ajaran 2010/2011". (skripsi). Pekanbaru: tidak diterbitkan.

Syaiful Bahri Djamarah. 2008. Psikologi Belajar. Jakarta : Rineka Cipta.

Toha Anggoro. 2007. Metode Penelitian. Jakarta : Universitas Terbuka.

Winarno Surakhman. 1985. Pengantar Interaksi Mengajar Belajar. Bandung: Tarsit. 